\title{
POTENSI EKSTRAK Jatropha multifida TERHADAP EKSPRESI VEGF APHTHOUS ULCER Rat norvegicus
}

\author{
Ch. Destri ${ }^{1)}$, I Ketut Sudiana ${ }^{2)}$, Jusak Nugraha ${ }^{3)}$ \\ 1) Dosen Fakultas Ilmu Kesehatan, Universitas Maarif Hasyim Latif, Sidoarjo \\ 2) Guru Besar Fakultas Kedokteran, Universitas Airlangga \\ 3) Guru Besar Fakultas Kedokteran, Universitas Airlangga \\ Email : destridali@yahoo.com
}

\begin{abstract}
Aphthous ulcer is the most common oral mucosal disease occurring in up to $25 \%$ of the world's human population. In general, therapy is more directed to pain control and hope of faster healing. Increased use of the drug with the original content on the grounds more free toxic effects, easy to obtain and affordable prices cause the use of plants as ingredients of medicine to be an alternative choice. Jatropha multifida known as betadin plant is a plant with bioactive ingredients flavonoids, diterpenoid, tannins and saponins have been widely used as medicinal plants. Research on aphthous ulcer in mouth mucosal of Rat norvegicus was made by using heated burnisher and using 54 Rat norvegicus rats divided into five groups were normal group, $\mathrm{K} 0$ (CMC-Na3\%), P1 (2.5\% JM); P2 (5\% JM) and P3 (JM 10\%). Giving a topical extract of J.multifida done 2 times a day then sacrificed on day 3 and day 5. VEGF expression in aphthous ulcer in the mouth tissue by immunohistochemical staining. The result of statistical analysis on VEGF expression showed significant difference $(\mathrm{p}<0,05)$ at concentration of J.multifida $10 \%$ extract where the wound healing process in mouse mucosa was better.
\end{abstract}

Keywords: Aphthous ulcer, Vascular endothelial growth factor, Jatropha multifida

\section{PENDAHULUAN}

Sariawan merupakan kondisi peradangan pada mukosa mulut yang ditandai rasa sakit dengan satu atau beberapa ulkus (S.S. Natah et al., 2004). Berdasarkan studi penelitian terakhir, perkembangan sariawan dimediasi secara genetik sehingga mampu mempengaruhi peran penting dari imunitas innate dan acquired. Berbagai faktor pencetus terjadinya modifikasi respon imun antara lain trauma mekanik, alergi makanan, defisiensi vitamin dan mikroelement, gangguan hormon dan gastrointestinal, beberapa infeksi virus dan bakteri serta stress (Zuzanna Slebioda, 2013). Faktor risiko yang paling umum adalah trauma. Hal ini dapat disebabkan oleh bibir atau pipi yang tergigit, abrasi dari makanan keras, proses menyikat gigi atau peralatan gigi. Makanan penyebab abrasi memungkinkan masuknya bakteri atau alergen (Ronald G. Shasy, 2000). Faktor trauma paling banyak menimbulkan pembentukan ulcer pada satu individu, menimbulkan kematian transepithelial yang bersifat apoptosis masiv dan mendadak diikuti timbulnya secondary necrosis yang mengarah pada pelepasan danger signal yang berasal dari sel epitel yang kemudian diikuti pengelupasan lapisan sel epitel mati dan terbentuklah ulcer (Al Samadi, 2015). Proses penyembuhan luka pada jaringan lunak di dalam rongga mulut mempunyai prinsip yang sama dengan bagian tubuh lain misalnya kulit. Penyembuhan luka selalu diawali dari proses pembekuan darah yang secara inisial bertujuan untuk menutup luka (Hannu larjava, 2012). Penyembuhan luka merupakan suatu rangkaian proses dengan dinamika begitu tinggi dan tepat terdiri dari tahapan yang saling mengikuti diawali dari 
tahap inflamasi, proliferasi sel, deposisi matrik hingga fase remodeling. Semua fase perbaikan termasuk fase inflamasi, re-epitelisasi dan pembentukan granulasi jaringan merupakan bagian yang dipengaruhi secara kompleks oleh growth factor dan sitokin yang secara langsung mengarah ke area luka (Sule Coskun et al., 2007). Pada kaskade penyembuhan luka secara normal selalu diawali dengan proses yang berlangsung secara tertib dari proses hemostasis dan deposisi fibrin yang kemudian mengarah pada kaskade sel-sel inflamasi yang dikarakterkan oleh neutrophyl/netrofil, macrofage/makrofag dan lymphosit/limfosit pada area luka. Proses ini kemudian diikuti dengan penarikan dan proliferasi fibroblast dilanjutkan dengan penumpukan dan remodeling oleh kolagen hingga terjadi pematangan bekas luka (Robert F. Diegelmann, 2004). Vascular Endothelial Growth Factor (VEGF) juga dikenal sebagai vascular permeability factor yang aktifitasnya berpotensi dalam meningkatkan vasopermiabel yang memungkinkan perembesan protein seperti fibrinogen dan fibronektin yang merupakan bentuk essensial dari provisional matrik.

VEGF juga berperan sebagai mitogen potent dari sel endotel yang menginduksi migrasi dan pertunasan sel endotel dalam pembentukan pembuluh darah baru melalui pengaturan beberapa reseptor integrin sel endotel (Ricardo Jose de Mendoca, 2012). Peran VEGF dalam penyembuhan luka adalah sebagai stimulator terjadinya angiogenesis. Angiogenesis pada proses penyembuhan luka melibatkan berbagai tahapan yaitu vasodilatasi, degradasi basement membrane, migrasi sel endotel dan proliferasi sel endotel. Diikuti dengan terjadinya pembentukan pembuluh kapiler, anastomosis pertunasan parallel capillary dan diakhiri pembentukan basement membrane baru. Fitur essensial dari perbaikan luka secara normal adalah terbentuknya jaringan granulasi. Komponen vaskular yang mempengaruhi tergantung pada proses angiogenesis. Pembentukan pembuluh darah baru terlihat paling awal 3 hari setelah luka. Pertumbuhan pembuluh darah kapiler pada luka berfungsi untuk menyalurkan nutrisi dan berbagai mediator penyembuhan serta membrane metabolite. Inhibisi terhadap angiogenesis akan melemahkan proses penyembuhan luka (Phillip Bao et al., 2009).

Perkembangan resistensi antibiotik mikrobial menjadi alasan pencarian global untuk antimikroba dengan kemurnian alami seperti pada tanaman asli. Jatropha multifida Linn merupakan tumbuhan tahunan berbentuk semak dengan tinggi 2-3 meter. Jatropha berasal dari bahasa Yunani "jatros" yang berarti dokter dan "trophe" berarti makanan. Tumbuhan ini banyak ditemukan di daerah tropis sepanjang Indo-Malayan, Amerika bagian tropis, Afrika bagian tropis serta beberapa daerah sub-tropis seperti Afrika Utara, Madagaskar dan Mauritius. Afrika, Asia dan Amerika Latin telah menggunakan spesies jatropha sebagai tumbuhan obat tradisional. Studi fitokimia dari berbagai spesies Jatropha mengungkapkan adanya kandungan alkaloid, cardiac-glycoside, flobatannis, flavonoid, tannin, dan saponin. Extraksi bagian daun Jatropha multifida L. dengan etil asetat didapatkan dua C-glycosyl flavone dengan struktur dibedakan atas Vitexin dan Isovitexin (Beatrize C.K. Hirota et al., 2012). Berbagai bagian tanaman Jatropha seperti minyak dari biji, getah, daun, kulit pohon dan akar dapat bermanfaat untuk menyembuhkan penyakit kulit seperti eksim, gatal, bisul, sariawan dan luka bengkak (Carla W. Sabandar et al., 2012)

\section{METODOLOGI PENELITIAN}

Jenis penelitian adalah penelitian eksperimental murni laboratorium (True Eksperimental) dengan rancangan penelitian Post Test Only Control Group Design. Perlakuan dalam empat konsentrasi ekstrak Jatropha multifida yang berbeda diberikan pada empat kelompok tikus dengan masing-masing kelompok 6 kali ulangan pada dua kelompok 
hari yang berbeda. Selanjutnya hasil data ekspresi VEGF yang diperoleh dilakukan analisa data statistik dengan mengetahui data terdistribusi normal memakai uji Kolomogrof Smirnov test. Distribusi normal yang didapatkan selanjutnya dianalisa menggunakan uji anova dan apabila terdapat perbedaan bermakna dilanjutkan dengan uji LSD dan uji t untuk mengetahui perbedaan pengamatan antara kelompok hari ke-3 dan hari ke-5.

\section{Waktu dan Tempat Penelitian}

Waktu penelitian dikerjakan selama tiga bulan. Lokasi penelitian dilakukan di beberapa tempat yaitu Laboratorium Balai Penelitian dan Konsultasi Industri untuk membuat gel ekstrak daun Jarak tintir (Jatropha multifida L), Unit hewan coba laboratorium Biokimia FK Universitas Airlangga untuk pemberian perlakuan dan Unit Mikroskop Elektron dan Laboratorium medis terpadu Fakultas Kedokteran Universitas Airlangga untuk preparat histokimia dan imunhistokimia.

\section{Alat dan Bahan Penelitian}

Peralatan dan bahan yang dipakai dalam penelitian ini antara lain bejana maserasi, peralatan gelas, neraca analitik untuk mengukur berat ekstraksi yang diperlukan, refrigerator incubator shacker (Lab-line), rotary evaporator dengan pompa vakum, kandang tikus, penggaris, cotton bud steril digunakan untuk mengolesi ulser/ulkus dengan Gel ekstrak Jatropha multifida $L$, spidol warna-warni sebagai penanda mencit, gelas ukur, gunting bedah, pinset berkerat dan pinset chirurgis, corong dan mesin penyaring larutan, botol kecil digunakan untuk tempat sediaan dalam rendaman larutan formalin $10 \%$, evaporator, mikroskop foto digital yang terhubung dengan computer. Sampel daun Jatropha multifida L yang sudah dikeringkan, bahan pembuatan ekstrak daun Jatropha multifida, satu set bahan dasar sediaan gel (CMC-Na 3\%), satu set bahan untuk sediaan histologis, pewarnaan HE, reagen kit pewarnaan imunhistokimia, Kertas
Whatman, aluminium foil, makanan tikus, aquades steril, Ethanol 96\%, Formalin 10\%, Ketamin untuk anastesi.

\section{ProsedurPembuatan sediaan ekstrak daun Jatrophamultifida $\mathbf{L}$}

Pembuatan ekstrak dilakukan di laboratorium Balai Penelitian dan Konsultasi Industri Surabaya - Jawa Timur dengan cara sebagai berikut : Daun Jatropha multifida L dikeringanginkan tanpa terkena sinar matahari secara langsung selama 6-9 hari. Daun yang sudah kering dihaluskan dengan alat (sehalus mungkin) dan ditimbang untuk mengetahui berat keringnya. Selanjutnya daun hasil pengeringan direndam dalam etanol $96 \%$ dibiarkan selama \pm 24 jam, setelah itu disaring untuk diambil filtratnya.

\section{Pembuatan gel dengan menggunakan Carboxy Methyl Cellulose-Na (CMC-Na 3\%)}

Dosis ekstrak gel 2,5\%, 5\% dan $10 \%$ dibuat dengan cara mencampur 2,5 gr,5 gr dan 10 gr ekstrak daun Jatropha Multifida $L$ ke dalam masing-masing 100gr bahan dasar gel. Setelah itu semua bahan dimasukkan ke dalam wadah tertutup dan diberi label.

\section{Perlakuan pada hewan coba tikus putih Rat norvegicus}

Tikus diadaptasikan dengan kondisi lingkungan penelitian selama 1 minggu, kemudian dibagi menjadi 2 kelompok (kelompok normal dan kelompok yang dibuat sariawan), kemudian kelompok yang dibuat sariawan dibagi menjadi 4 kelompok dan dibagi lagi menjadi 2 kelompok yaitu (kelompok pada hari ke 3 dan 5), kecuali kelompok kontrol hanya 1 kelompok (hari ke 5). Setiap mencit ditimbang dan dimasukkan kedalam kandang berukuran $20 \times 15 \times 15 \mathrm{~cm}$. Anastesi dengan menggunakan ketamin hingga tikus sudah dalam keadaan tenang dan hanya terlihat pernafasan perut, maka perlakuan harus segera dilakukan. Keadaan anastesi terjadi dalam waktu 5-10 detik. Kemudian mukosa bibir 
bawah tikus dilukai dengan burnisher nomor 4 dengan penampang $\pm 2 \mathrm{~mm}$ yang dipanaskan selama 1 menit dan disentuhkan selama 1 detik. Pada umumnya sariawan akan terbentuk pada hari ke-2 atau ke-3.. Pemberian gel ekstrak Jatropha multifida L $(2,5 \%, 5 \%, 10 \%)$ dimulai setelah terbentuk ulser pada daerah tersebut $2 \mathrm{x}$ sehari. Aplikasi gel ekstrak menggunakan cotton bud steril. Untuk kelompok kontrol negatif menggunakan bahan dasar gel yang diaplikasikan pada daerah ulser. Pada hari ke-3 dan ke-5 setelah perlakuan, setiap kelompok termasuk kelompok kontrol negative dikorbankan dengan menggunakan ketamin sebagai anastesi. Kemudian mukosa bibir bawah dipotong sampai sudut mulut tikus mengikuti bagian yang ulser dan bagian yang normal dimasukkan kedalam larutan fiksasi dan selanjutnya tikus yang telah mati dikubur.

\section{Pemeriksaan pada preparat jaringan}

Jaringan mukosa bibir tikus dengan luka sariawan yang telah direndam dalam larutan buffer formalin $10 \%$ selama 24 jam selanjutnya diproses dengan metode parafin hingga didapatkan blok parafin dan dibuat preparat untuk pewarnaan imunohistokimia.

\section{Pewarnaan imunohistokimia VEGF}

Prosedur pewarnaan dengan memakai antibodi monoklonal anti rat vascular endothelial growth factor dilakukan pada preparat dengan terlebih dahulu dilakukan deparafinisasi pada larutan xylol kemudian etanol dengan konsentrasi menurun. Selanjutnya pemberian peroksida $3 \%$ digunakan untuk menghilangkan peroksidase endogeneous kemudian dicuci dengan PBS. Pemberian trypsin $0,025 \%$ dalam larutan PBS dilakukan selama 6 menit pada suhu $37^{\circ} \mathrm{C}$ yang dilanjutkan dengan pemberian primer antibodi monoklonal VEGF selama 30 menit, dicuci dengan PBS. Selanjutnya pemberian antibodi sekunder selama 30 menit, dicuci dengan PBS kemudian preparat dimasukkan dalam streptavidin HRP selama 30 menit, cuci kembali dengan PBS, dimasukkan kembali ke dalam substrat kromogen selama 5 menit, cuci dengan PBS kemudian aquadestilata, pemberian Mayer Hematoksilin selama 6 menit dan terakhir kembali dibilas dengan air mengalir. Amati hasil pewarnaan dan dilakukan penghitungan sel makrofag yang mengekspresikan VEGF dalam 5 lapangan pandang berbeda dengan pembesaran 400x.

\section{HASIL DAN PEMBAHASAN HASIL}

Data penelitian untuk ekspresi VEGF berupa hasil perhitungan rerata makrofag yang mengekspresikan VEGF dalam 5 lapang pandang mikroskop cahaya pembesaran 400x pada preparat yang memakai tehnik pewarnaan imunhistokimia dengan monoklonal antibodi. Dalam setiap lapang pandang diklasifikasikan sel $\mathrm{P}(+)$ apabila ditemukan inti sel besar dengan sitoplasma yang berwarna kecoklatan/ hitam keunguan dan sel $\mathrm{N}(-)$ apabila inti sel besar atau kecil dengan sitoplasma berwarna kebiruan atau jernih. Data hasil penelitian selanjutnya dianalisis secara statistik deskriptif untuk memperoleh gambaran lebih lanjut mengenai distribusi, rerata, simpangan baku dan perbedaan dari tiap variabel penelitian.

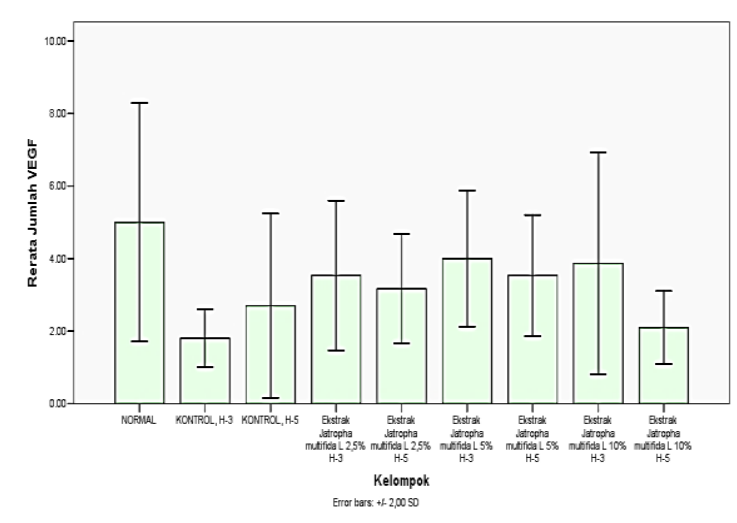

Gambar 1. Distribusi dan Rerata Ekspresi VEGF

Dari hasil perhitungan ekspresi VEGF yang ditampilkan oleh makrofag didapatkan bahwa ekspresi VEGF paling tinggi ada di hari 
ke-3 pada dosis $10 \%$ sedangkan ekspresi VEGF pada hari ke-5 didapatkan paling tinggi pada

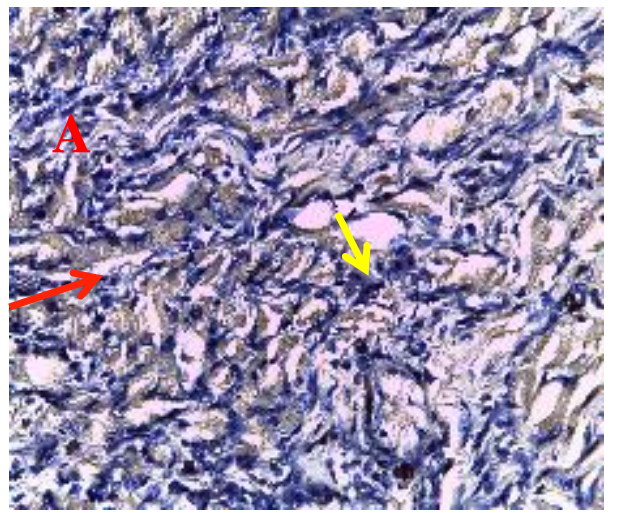

dosis 5\%. Secara umum ekspresi VEGF pada hari ke-5 lebih rendah dibandingkan hari ke-3.

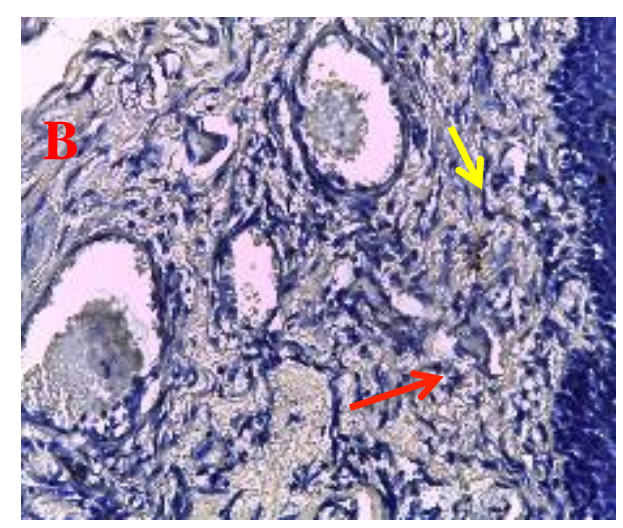

Gambar 2. Gambar A adalah preparat mukosa mulut tikus Rat norvegicus dengan ulcer pembesaran 400x pewarnaan imunohistokimia dari kelompok P3 (10\%) hari ke-3. Sel makrofag yang mengekspresikan VEGF mempunyai ciri khas sel berinti besar dengan sitoplasma berwarna kecoklatan (tanda panah kuning), sedangkan bentuk sel makrofag yang tidak mengekspresikan VEGF dikarakteristikkan sebagai sel berinti besar dengan sitoplasma berwarna kebiruan (tanda panah merah). Gambar B adalah preparat mukosa mulut tikus Rat norvegicus dengan ulcer pembesaran $\mathrm{x} 400$ pewarnaan imunohistokimia dari kelompok P3 (10\%) hari ke-5.

Tabel 1. Hasil uji beda sel makrofag yang mengekpresikan VEGF

\begin{tabular}{lccccc}
\hline \multicolumn{1}{c}{ Kelompok } & $\mathrm{N}$ & Hari ke-3 & Hari ke-5 & Pest) \\
\hline Normal & 6 & $5,00 \pm 1,64^{\mathrm{a}}$ & $5,00 \pm 1,64^{\mathrm{a}}$ & \\
Kontrol(CMCNa3\%) & 6 & $1,80 \pm 0,40^{\mathrm{b}}$ & $2,70 \pm 1,26^{\mathrm{bc}}$ & 0,221 \\
P1 (Jm 2,5\%) & 6 & $3,53 \pm 1,03^{\mathrm{ac}}$ & $3,16 \pm 0,75^{\mathrm{bc}}$ & 0,498 \\
P2 (Jm 5\%) & 6 & $4,00 \pm 0,93^{\mathrm{c}}$ & $3,53 \pm 0,83^{\mathrm{b}}$ & 0,384 \\
P3 (Jm 10\%) & 6 & $3,86 \pm 1,52^{\text {ac }}$ & $2,10 \pm 0,50^{\mathrm{c}}$ & 0,023 \\
Nilai p (Anova) & & 0,002 & 0,001 & \\
\hline Ken
\end{tabular}

Keterangan: Berbeda huruf superskrip menunjukkan adanya perbedaan bermakna menggunakan uji komparasi berganda LS (nilai $\mathrm{p}<0,05$ )

Dari uji beda antara hari ke-3 dan hari ke5 diketahui bahwa perlakuan P3 yaitu kelompok yang diberikan ekstrak Jatropha multifida konsentrasi $10 \%$ mempunyai pengaruh yang paling signifikan terhadap penurunan ekspresi VEGF pada proses penyembuhan Aphthous Ulcer mukosa mulut tikus Rat norvegicus.

\section{PEMBAHASAN}

Vascular endothelial growth factor (VEGF) merupakan faktor yang signifikan terhadap proses penyembuhan luka yang berlangsung dengan segera setelah terjadi perlukaan. VEGF secara potensial mengurangi hipoksi jaringan dan defisiensi metabolisme dengan mempromote/promosikan awal terjadinya angiogenesis dan fungsi endotel. Aktifitas maksimal terjadi rata-rata 3-7 hari setelah luka. Pada saat luka telah membentuk granulasi jaringan, maka angiogenesis akan berhenti, pembentukan pembuluh darah berkurang dan sel endotel mengalami apoptosis (J.M Reinke, 2013). Dari uji beda secara statistik didapatkan bahwa antara hari ke-3 dan hari ke-5, perlakuan P3 yaitu kelompok yang diberikan ekstrak Jatropha multifida konsentrasi $10 \%$ mempunyai pengaruh paling signifikan terhadap penurunan ekspresi VEGF 
pada proses penyembuhan Aphthous Ulcer mukosa mulut tikus Rat norvegicus, sedangkan hasil uji beda ekspresi VEGF antara hari ke-3 dan hari ke-5 di kelompok normal menunjukkan tidak ada perbedaan. Hal ini menunjukkan bahwa ekspresi VEGF yang tanpa luka tidak banyak mengalami perubahan. Dari setiap kelompok perlakuan yaitu kelompok P1 (2,5\%), kelompok P2 (5\%) dan kelompok P3 (10\%) secara rerata menunjukkan ekspresi VEGF mengalami penurunan. Hal ini berarti dengan adanya perlakuan pemberian ekstrak Jatropha multifida yang mengandung bahan bio aktifitas mampu memicu kesembuhan yang lebih cepat. Dari setiap perlakuan diketahui pula bahwa dari kelompok P3 (10\%) terdapat penurunan yang signifikan $(p<0,05)$. Hal ini menunjukkan bahwa pada konsentrasi tertinggi dimana jumlah penurunan VEGF lebih banyak dibandingkan dengan dua perlakuan yang lain, sehingga dapat diketahui bahwa konsentrasi ekstrak Jatropha multifida dengan konsentrasi $10 \%$ mampu mempercepat proses penyembuhanyang diindikasikan dengan menurunnya ekspresi VEGF yang secara teori dikatakan bahwa pada pembentukan pembuluh darah yang telah matang ditandai dengan menghilangnya signal VEGF di area luka.

\section{KESIMPULAN}

Berdasarkan data hasil statistik dari penelitian ini diperoleh hasil bahwa pemberian ekstrak Jatropha multifida dapat mempengaruhi ekspresi VEGF pada kadar 10\%. Pengaruh ekstrak jarak tintir (Jatropha multifida) pada konsentrasi $10 \%$ berpengaruh lebih baik terhadap ekspresi VEGF karena ekspresi VEGF yang tinggi pada hari ke-3 kemudian berhenti di hari ke-5 menunjukkan telah dimulainya pembentukan pembuluh darah baru yang mendukung proses penyembuhan lebih baik.

\section{UCAPAN TERIMAKASIH}

Ucapan terima kasih disampaikan oleh penulis kepada seluruh pihak Laboratorium terpadu Fakultas Kedokteran Universitas Airlangga dan staf laboratorium imunologi Fakultas Ilmu Kesehatan UMAHA yang telah banyak membantu dalam penelitian ini.

\section{DAFTAR PUSTAKA}

Anabel Diaz, Otilia Pereira-Lopez, Elisabete Barbosa, Pedro Mesquita, Filipe Coimbra, 2015. Behaviour of The Recurrent Aphthous Stomatitis as a Dental Urgency at Vedado's university Policlinic. Faculty of Detal Medicine, University of Porto - Original Research. Portugal.

Aceng Ruyani, Agus Sundaryono, Hery Haryanto, 2010. Pengembangan Tumbuhan Betadine (Jatropha multifida Linn.) Untuk Meningkatkan Jumlah Trombosit pada Penderita Penyakit Demam Berdarah Dengue. FKIP Universitas Bengkulu. Indonesia

Al Samadi, A. Drozd, A Salem, J. Hietanen, R. Hayrinen-Imonen, Y.T. Konttinen, 2015. Epithelial Cell Apoptosis in Recurrent Aphthous Ulcer. Journal of Dental Research vol. 94 (7) 928-935. Institiute of Clinical Medicine Biomedicum, Helsinki. Finland.

Anthony L. Mescher, 2013. Basic Histology Text and Atlas. Thirteenth edition. McGraw Hill e-book. Indiana

Beatrize C. K. Hirota, Cristina M.S. Miyazaki, Camila A. Mercali, Maria C. Verdan, Milena Kalegari, Carlos Gemin, Ana L.L. Lordello, Marilis D. Miguel, Obdulio G. Miguel, 2012. C-Glycosyl Flavones and Comparative Study of The Antioxidant, Hemolytic, and Toxic Potential of Jatropha multifida Leaves and Bark. International journal of Phytomedicine 4. 01-05. Brazil.

Bodhu Sashi Kanth, Avula Satya Kumar, Digambar Balaji Shinde, Kothapali Hari 
Babu, Tuniki Venugopal Raju, Chityal Ganesh Kumar, Pombala Sujitha, Biswanath Das, 2011. New Bioactive Macrocyclic Diterpenoid from Jatropha multifida. Journal Elsevier Bioorganic and Medicinal Chemistry Letters 21 (2011) 6808-6810. India.

G. Leoni, P.A. Neumann, R. Sumagin, T.L. Dening, A. Nusrat, 2015. Wound Repair : Role of Immune - EpithelialInteraction. Mucosal Immunology. Nature Publishing Group. Review

Hannu Larjava, 2012. Oral Wound Healing : Cell Biology and Clinical Management. Ulcer Healing Book. Vancouver, Canada

Jazwa Agniezka, Paulina Kucharzewska, Justyna Leja, Anna Zagorska, Aleksandra Sierpniowska, Jacek Stepniewski, Magdalena Kozakowska, Hevidar Taha, Takahiro Ochiyo, Rafal Derlacz, Elisa Vahakangas, Seppo Yia Herttuala, Alicja Jozkowics, Josef Dulak, 2010. Combined Vascular Endhotelial Growth Factor-A and Fibroblast Growth Factor 4 Gene Transfer Improves Wound Healing in Diabetic Mice. Genetic vaccines and therapy, 8:6. BioMed Central. Poland.

Lari Hakkinen, Leeni Koivisto, Jryki Heino, Hannu Larjava, 2015. Cell and Molecular Biology of Wound Healing. Laboratory of Periodontal Biology, Faculty of Dentistry, University of British Columbia, Vancouver. Canada.

Michael P. Seed, David A. Walsh, 2008. Angiogenesis in Inflammation : Mechanism and Clinical Correlates. Die Deutsche Bibliothek Basel, Boston. Berlin.

Phillip Bao, Arber Kodra, Marjana Tomic, Canic, Michael S. Golinko, H. paul Ehrlich, Harold Brem, 2009. The Role of Vascular Endothelial Growth Factor in Wound Healing. J. Surg Res. 153 (2) : 347-358
Rashkit K. Devappa, Harinder P.S. Makkar, Klaus Becker, 2010. Jatropha Toxicity- A Review. Journal of Toxicology and Environmental Health, Part B. Critical Reviews, Germany.

Ricky Z. Cui, Alison J. Bruce, Roy S. Roger, 2016. Recurrent Aphthous Stomatitis. Clinic in Dermatology. Arizona.

Robert F. Diegelmann, Melissa C. Evans, 2004. Wound Healing : An Overview of Acute, Fibrotic and Delayed Healing. Department of Biochemistry, Medical College of Virginia. Virginia Commonwealth University, Richmond. Virginia

Sule Coskun, Emine Gulceri Gulec, Barbaros Balabanli, 2007. Effect of Epidermal Growth Factor on Lipid Peroxidation and Nitric Oxide level in Oral Mucosal Ulcer Healing. A time course study surg. Today (2007) 37; 570-574, Gazi University, Ankara. Turkey.

Xiao Wen Jiang, Yi Zhang, Hao Zhang, Kun Lu, Shou-Kang Yang, Guo Liang Sun, 2013. Double Blind, Randomized, Controlled Clinical Trial of The Effect of Diomestite and Basic Fibrobast Growth Factor paste on Treatment of Minor Recurrent Aphthous Stomatitis. Oral Surg Oral Med Oral Pathol Oral Radiol, 2013; 116:570-575. University of South China, Chenzou, Hunan. China.

Zuzanna Slebioda, Elzbieta Szponar, Anna Kowalska, 2013. Etiopatogenesis of Reccurent Aphthous Stomatits and The Role of Immunologic Aspect : Literature Review. Poznan, Poland. 